Original scientific paper

UDK: 327.5:61.1 EU(497.11+497.115)

DOI: $10.5937 / J R S 1801065 \mathrm{P}$

Received: 27 October 2017 / Accepted: 1 April 2018

\title{
Towards a Comprehensive Framework of Mediation Success: EU Mediation in the Belgrade-Pristina Dialogue*
}

\author{
ERIK PLÄNITZ** \\ Arnold-Bergstraesser-Institute, Germany
}

\begin{abstract}
The European Union has gained increasing importance in international mediation over the last decade. Driven by the powerful role assigned to the High Representative and the European External Action Service by the Lisbon treaty, the EU has been facilitating high-level talks between Belgrade and Pristina over their relationship since 2011. Although the signing of the Brussels Agreement in 2013 was a breakthrough, developments in north Kosovo suggest that the process might have significant shortcomings. This paper's guiding research question of how to assess mediation success addresses the existing gap between external and internal perspectives. It introduces a comprehensive analytical framework to assess mediation success that combines several previously suggested ideas into a single framework. The question of how to measure successful mediation contributes not only to theory development but targets the interface between science and policymaking. The framework, as applied to the EU mediation efforts in the Belgrade-Pristina dialogue, has unveiled the in conclusive character of the process. Whilst being a success for the European Union, this paper argues a deficit in local legitimacy exists. Increasing levels of internal violence in Kosovo hint that it failed to fully address the root causes of the dispute.
\end{abstract}

Keywords: Mediation success, European Union, Serbia, Kosovo, dialogue.

* This project is part of EU-CIVCAP and has received funding from the European Union's Horizon 2020 research and innovation programme under grant agreement No 653227.

***erik.plaenitz@abi.uni-freiburg.de 


\section{Introduction}

Mediation and dialogue in peace processes, and as a preventive measure, have become increasingly popular tools of European Union (EU) conflict resolution. ${ }^{1}$ Western European engagement in peace formation in the Balkans dates back to the early days of the conflict linked with the disintegration of Yugoslavia. ${ }^{2}$

Visibly sidelined during the course of the Yugoslav conflict, the EU re-appeared on the diplomatic scene at the beginning of the $21^{\text {st }}$ century and the end of the Kosovo war. It returned to the table in 2001 with its role as co-mediator in the conflict between the $\mathrm{Na}$ tional Liberation Army (UCK) and the former Yugoslav Republic of Macedonia. The EU has become increasingly engaged in mediation in the Balkans region culminating in the Belgrade-Pristina dialogue. Under the auspices of the EU, status talks, started in March 2011, led to the signing of the Brussels Agreement in 2013. Equipped with a new role in the post-Lisbon architecture, the European External Action Service (EEAS) and the EU High Representative (HR) took the lead position in high-level talks between the Serbian and Kosovo prime ministers and presidents.

More than four years into the mediated normalization process, the rhetoric of high-level politicians and recent setbacks have questioned the success of the Belgrade-Pristina dialogue. When talking about success, research in the past has investigated various contextual factors and characteristics, including the conditions required for successful mediation. There is a considerable amount of literature and scholarly work considering mediation addressed from the perspective of how to make mediation successful, ${ }^{3}$ but rather little has been done on the issue of how to assess successful mediation. ${ }^{4}$

In order to address this shortcoming, this paper introduces a comprehensive framework to assess mediation success to be applied in evaluation and assessment of mediation efforts. It builds upon and then advances existing approaches to measure success. Previous research has either taken a one-sided view focusing merely on the mediator ${ }^{5}$ or put emphasis on the success of military operations. ${ }^{6}$ This has proved to be insufficient in fully covering and assessing the success or failure of the mediation processes. One objective of this paper is to better link the mediator and local conflict perspective and create a comprehensive framework. Beyond enhancing existing literature on mediation and dialogue, it serves as an analytical tool that may be applied during practical evaluation studies of mediation processes.

$1 \quad$ See for example Davis 2014; Girke 2015; Brandenburg 2017.

2 For a comprehensive discussion of EU engagement in the Balkans until 2000 see for example Hill and Smith 2000.

3 Kleiboer 1996; Beardsley 2011; Böhmelt 2011; Vuković 2014; Bercovitch and Fretter 2004; Bercovitch and Jackson 2009; Frazier and Dixon 2006.

4 Bercovitch 2006; Bergmann and Niemann 2015.

5 Bergmann and Niemann 2015.

6 Peen Rodt 2012; Pushkina 2006. 
Thereby, this article is relevant along two lines. Firstly, it further develops theoretical discussions; and secondly, it provides an analytical tool for policy evaluation.

By employing explorative qualitative modes of enquiry, I will attempt to test the comprehensive framework to assess mediation success by studying the Belgrade-Pristina dialogue. Despite the significant scholarly attention that has been directed at this mediation process, research so far has not adequately combined both the internal and external perspective as proposed in the framework. To date, research has addressed several pieces of the puzzle, but failed to provide a comprehensive perspective. Visoka found that multiple weak spots in the agreements contributed to the normalization of EU relations between EU and both countries rather than among the conflicting parties. ${ }^{7}$ In their study, Economides and Ker-Lindsay shed light on the motivations of Serbia to agree to dialogue. They found that Belgrade's policy was based on material concerns. ${ }^{8}$ Various studies have assessed the efficacy of the mediation strategy applied and criticized the approach of 'creative ambiguity' for producing vague results leaving too much room for misinterpretation. ${ }^{9}$ Moreover, the top-down approach and lack of transparency may jeopardize the entire peace process. ${ }^{10}$ The most promising and advanced article provided by Bergmann and Niemann examined the EU's effectiveness as a mediator and rated it as medium. The authors stated that the EU utilizes leverage, while lacking coherence and spoilers tarnish the balance of EU effectiveness. ${ }^{11}$ This paper builds on the work done by Bergmann and Niemann and aims to enhance their analytical scheme.

Application of the comprehensive framework revealed the rather ambivalent picture of the mediation process. While the internal perspective can be regarded as a success given the EU has mainly achieved its goals and acted coherently, the external perspective differs considerably. Despite the launch of the overall normalization process, this research suggests that conflict on the local level has increased and the mediation process as such lacks local legitimacy. ${ }^{12}$ It is perceived as 'elite-captured' ${ }^{\prime 13}$ with little or no ties to local civil society.

Before delving into the case study, this paper outlines the theoretical debates on mediation success in section two and introduces the subsequent comprehensive framework in section three. Section four applies the comprehensive framework presented in section three to the case study.

7 Visoka 2017.

8 Economides and Ker-Lindsay 2015.

9 Gashi, Musliu, and Orbie 2017; Bieber 2015.

10 Beha 2015.

11 Bergmann and Niemann 2015.

12 Demjaha 2017; Ernst 2014.

13 Plänitz and Stojanović Gajić 2017. 


\section{Debates on Mediation Success}

Broadly speaking, 'mediation' as an approach and part of the conflict management toolbox aims at finding non-violent solutions to a given conflict. ${ }^{14}$ The process involves conflict parties and a mediator negotiating on a voluntary basis. ${ }^{15}$ Bercovitch, Anagnoson and Wille introduced a definition that is applied throughout this paper. Accordingly, mediation describes "a process of conflict management where the disputants seek the assistance of, or accept an offer of help from, an individual, group, state or organization to settle their conflict or resolve their differences without resorting to physical violence or invoking the authority of the law." ${ }^{16}$

The choice of appropriate mediation strategies is considered to be crucial to the outcome of the conflict-solving engagement. As Bercovitch and DeRouen put it, a "mediation strategy is an overall plan of mediators to resolve and manage conflicts". ${ }^{17}$ They identify three types of strategies of mediation. ${ }^{18}$ (I) Communication-facilitation strategies involve the mediator taking a passive role and concentrating on facilitating the process.(II) Procedural-formulative strategies position the mediator in control of the formal setting that may include responsibility for media publicity, distribution of information or determination of structural aspects of meetings. The most powerful (III) directive strategy enables the mediator to directly influence negotiations by offering incentives. ${ }^{19}$ Taking the latter role requires some extent of power to lead a carrot-and-stick tactic and draws on the manipulative capacity of the mediator. ${ }^{20}$ Beardsley concludes that peace agreements based on a directive strategy have a rather short life expectancy of 5 to 10 years. ${ }^{21}$ The same line is taken by Gartner, who found that although this strategy increases the likelihood of reaching a full settlement, it is associated with a negative effect on durability. This result can be ascribed to the fact that directive strategies are often applied on intractable conflicts and fragile settlements. ${ }^{22}$

However, when looking at desired outcomes a directive strategy can indeed lead to a desired result. Wilkenfeld et al. argue that a manipulative approach, using the mediators' po-

14 For extensive reviews see for example Wall, Standifer and Stark 2001; Wallensteen and Svensson 2014.

15 Bercovitch and DeRouen 2004, 154.

16 Bercovitch, Anagnoson and Wille 1991, 7.

17 Bercovitch and DeRouen 2004, 156.

18 For an in-depth discussion on mediation strategies see for example Bercovitch and DeRouen 2004.

19 Bercovitch and Fretter 2004, 157.

20 Zenelaj, Beriker and Hatipoglu 2015.

21 Beardsley 2011.

22 Gartner 2014. 
sition and leverage, is more likely to be successful in terms of crisis management. ${ }^{23}$ Acute crisis termination is best achieved with directive strategies, whereas facilitative mediation contributes to a reduction of post-crisis tensions. ${ }^{24}$

\section{Studying Mediation Success}

The first approaches to theorizing the success of mediation effort date back to Frei, defining success as the pure existence of a mediation process. ${ }^{25}$ Sheppard enhanced the conceptualization by adding the "process" to the "outcome" dimension. She referred to the 'process' as everything happening during the procedures and the 'outcome' describes the result of the mediation. ${ }^{26}$ Within those two categories, Sheppard, but also Katz Jameson identified four different criteria signifying success: fairness, efficiency, satisfaction and effectiveness. ${ }^{27}$ Kleiboer provided the first extensive discussion on debates circling about the understanding of mediation success.$^{28}$ Supporting the notion of Frei, Kleiboer identified another school of scholars arguing that success is equal to cease fire and a full or partial settlement of the conflict. ${ }^{29}$ Contemporary scholarship tends to take the arguments of the second category of research, namely 'outcome.' However, building on indicators such as ending violence, the signing of peace agreements and the establishment of democratic institutions take a rather conflict oriented approach of assessing mediation success. ${ }^{30}$ Hence, a group of researchers focused on the effectiveness. Accordingly, mediation can be considered successful, if the parties or mediators achieved their goals set at the beginning. ${ }^{31}$

Despite categorizing mediation outcome into successful and failed, little attempt was made to unpack the assessment of mediation success. As one of the few examples that discusses the relationship between both the conflict and mediator perspective, Bercovitch concludes that "too often, it seems success or failure is assumed, postulated, or defined on a case-by-case basis, and usually in an arbitrary and poorly reasoned manner". 32 Although, the author calls for a more comprehensive discussion, the article does not provide a workable framework for assessing mediation success. This paper argues that the main limitations arise from these distinctions between conflict and mediator based

23 Wilkenfeld et al. 2003.

24. See for example Beardsley 2006; Bercovitch and Sigmund Gartner 2006.

25 Frei 1976.

26 Sheppard 1984.

27 Sheppard 1984; Katz Jameson 1999.

28 Kleiboer 1996.

29 See for example Bercovitch, Anagnosnon and Wille 1991; Kriesberg and Thorson 1991.

30 See for example Regan and Aydin 2006; Regan and Stam 2000; Nathan 1999; Savun 2008; Beardsley 2006.

31 Smith 1985; Touval and Zartman 1985.

32 Bercovitch 2006, 289. 
perspective. It therefore seeks to bridge the gap and proposes that mediation success is dependent on both external (conflict perspective) and internal (mediator perspective) effectiveness.

The first comprehensive framework stemming from military conflict management was provided by Peen Rodt. She divides the operationalization of success into two sub-categories, namely the internal EU perspective that evaluates an operation from the mediators' standpoint, and the external conflict perspective, taking a conflict specific position. ${ }^{33}$ While the former focuses on the fulfillment of political goals and internal procedures, the latter looks into the outcome and results of mediation. Following Peen Rodt's model, both perspectives are therefore further clustered into criteria on how the mission performed and achieved its targets (Internal \& External Goal Attainment) and secondly, the way of achieving it (Internal \& External Appropriateness).

Another contribution towards a comprehensive framework has been made by Bergmann and Niemann who introduced an operationalization of EU effectiveness in mediation processes. They analyzed both European goal attainment and conflict settlement. Mediator effectiveness was examined using the variables of mediator leverage, mediation strategy, coherence and conflict context. ${ }^{34}$

The next section moves beyond these existing approaches and proposes a comprehensive framework of mediation success.

\section{Towards a Comprehensive Framework of Mediation Success}

In order to establish a comprehensive framework to assess mediation success that entails both perspectives, this paper draws on the scheme of success in military conflict management introduced by Peen Rodt, and merges it with a set of indicators provided by Bergmann and Niemann. The proposed framework (Figure 1) considers both, the internal and external effectiveness that are further explained in the following section.

33 Peen Rodt 2012.

34. Bergmann and Niemann 2015. 


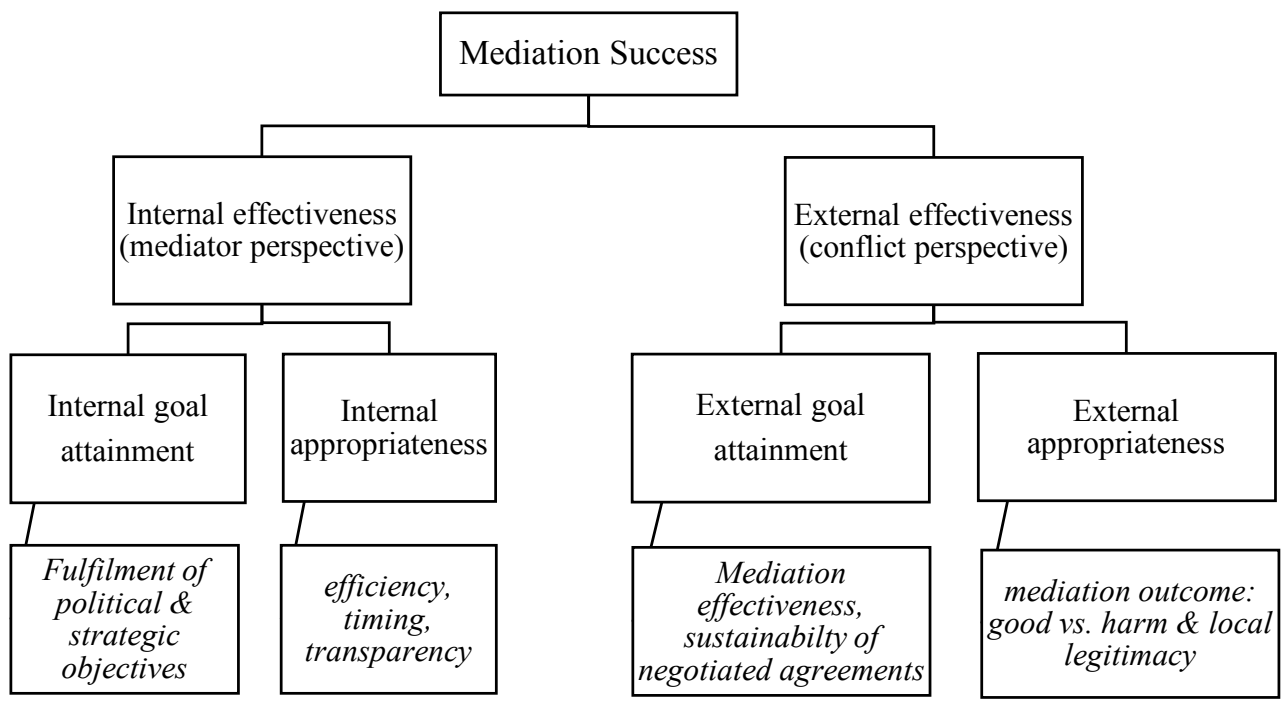

Figure 1: Analytical Framework based on Peen Rodt (2012) and Bergmann and Niemann (2015.)

\section{Internal Effectiveness}

The underlying premise of this category is that mediators have their own agenda and political goals. Mediation is considered to be a tool of foreign policy. ${ }^{35}$ Subsequently, this category studies the mediators' agenda as well as political goals and considers how it matches with the actual mediation outcome.

More specifically, the sub-category 'internal goal attainment' assesses to what degree the mediator has achieved their goals set at the beginning. It is operationalized using the indicator 'fulfillment of political \& strategical objectives. Following Bergmann and Niemann who suggest a three-scale measurement, high levels are related to the achievement of most or all goals, medium level is linked to some goals achieved and low levels represent fulfillment of some minor goals or nothing at all. ${ }^{36}$

The sub-category internal appropriateness includes the indicators 'efficiency', 'timing' and 'transparency'. Built upon the body of literature that deals with the 'timing' of mediation, this scale ranges from high to low. The scholarly basis was established by Zartman, who introduces the theory of mutual hurting stalemate (MHS) and his concept of 'ripeness'. The idea behind this is rooted in diplomatic circles that describe 'ripeness' as the point

35 Touval 2003.

36 Bergmann and Niemann 2015. 
in time when a stalemate has been reached, suggesting that the conflict is then ripe for mediation. A more elaborated concept of MHS "is based on the notion that when the parties find themselves locked in a conflict from which they cannot escalate to victory and this deadlock is painful to both of them (although not necessarily in equal degree or for the same reasons), they seek an alternative policy or Way Out". ${ }^{37}$ This concept is backed and proven relevant by a number of studies on peace mediation. ${ }^{38}$ Kriesberg and Thorson (1991) find that the conflict has to have gone through "some phases, moves, and countermoves before a serious attempt to mediate it should be made" ${ }^{39}$ By reaching a point where conflict parties have had high costs and have realized that continued conflict will worsen their situation, mediation may be successful. ${ }^{40}$ On the contrary, Edmead suggests that mediation efforts should take place as early as possible to eradicate disputes before the positions become fixed. ${ }^{41}$ Others study the role of a specific mediator that helps to achieve a convenient result for one of the conflict parties providing the chance to excuse compromises that have to be made in the process. ${ }^{42}$ Beardsley argues that a state is more interested in becoming involved as a mediator in cases with high intensity of armed conflict and proximity to its own borders. ${ }^{43}$ In other words, the closer the conflict is, the more likelihood of intervention as a mediator. This is reflected in the timing scale ranging from high to low. High represents the school of scholars arguing for early interventions, medium stands for a conflict that had been through some phases before mediation takes place and lastly, low translates into total deadlock between conflict parties. The grade system of timing does not reflect a judgment but rather helps to rate the time of intervention and link it to other variables for analytical purposes.

The 'efficiency' of mediation mainly covers the questions of how the initiative has been linked to other operations in the area. Following the argumentation of Touval, mediation is a tool of foreign policy which implies that it can be complemented by other means of trade or security policy. ${ }^{44}$ This indicator studies whether there are synergies and overlaps or even contradictory activities with other operations of the mediator. Again, this paper suggests a scale ranging from high, through middle to low efficiency.

'Transparency' seems to be of particular interest with multilateral mediators, such as the EU. It examines the internal procedures of the mediators from the headquarters to representatives on the ground. A lack of transparency and sluggish vertical communication may hinder effective implementation of mediation and its outcomes. The contradictory

37 Zartman 2001, 8.

38 See for example Kleiboer 1996; Wall, Standifer and Stark 2001.

39 Diehl and Goertz 2000, 206.

40 Bercovitch and Diehl 1997.

41 Edmead 1971.

42 Maundi 2006; Michael Greig and Regan 2008; Beardsley 2011.

43 Beardsley 2011.

44. Touval 2003. 
goals of actors that are part of a multilateral agent may undermine effective mediation. The stronger the commitment of all parties, the higher the chance of mediation success.

\section{External effectiveness}

The category of external effectiveness distinguishes between external goal attainment and external appropriateness. External goal attainment is composed of the indicator on mediation effectiveness and sustainability of negotiated agreements as proposed by Bergmann and Niemann. They introduced a scale ranging from zero meaning 'no agreement reached' up to five representing a 'full settlement' of the conflict. ${ }^{45}$

The sub-category on external appropriateness focuses on the mediation outcome, more precisely on the indicators of good vs. harm done and local legitimacy of the mediation result. The latter studies local acceptance of the agreement reached, assuming that the implementation of a mediation contract will be challenging without acceptance of affected populations. In fact, this indicator does not evaluate the legitimacy of the mediator - a factor that has received major attention in the existing literature. ${ }^{46}$ However, recent research suggests that inclusive mediation approaches that include local agents are more durable than exclusive negotiations. ${ }^{47}$ This indicator assesses both the inclusiveness of the negotiations and the perception of the agreement among the affected population. The conceptualization of good vs. harm is established by Peen Rodt, assessing the "discrimination and proportion in the application of force" ${ }^{48}$

The matrix below (table 1) provides an overview of categories, sub-categories, indicators and the assessment scale.

45 Bergmann and Niemann 2015.

46 See for example Bercovitch and Schneider 2000.

47 See for example Jarstad and Sisk 2008; Nilsson 2012.

48 Peen Rodt 2012, 170. 


\begin{tabular}{|c|c|c|c|}
\hline Category & Sub-category & Indicators & Scale \\
\hline \multirow[t]{7}{*}{$\begin{array}{l}\text { Internal } \\
\text { effectiveness }\end{array}$} & $\begin{array}{l}\text { Internal goal } \\
\text { attainment }\end{array}$ & $\begin{array}{l}\text { Fulfillment } \\
\text { of goals and } \\
\text { objectives }\end{array}$ & $\begin{array}{l}\text { High (all/most goals achieved), } \\
\text { Medium (some major goals } \\
\text { achieved) }\end{array}$ \\
\hline & & & Low (only minor goals) \\
\hline & $\begin{array}{l}\text { Internal } \\
\text { appropriateness }\end{array}$ & Timing & $\begin{array}{l}\text { High (early phase of conflict), } \\
\text { Medium (conflict through some } \\
\text { phases) }\end{array}$ \\
\hline & & & Low (deadlock) \\
\hline & & $\begin{array}{l}\text { Efficiency, } \\
\text { Transparency }\end{array}$ & High (highly efficient/transparent) \\
\hline & & & $\begin{array}{l}\text { Medium (medium levels of } \\
\text { efficiency/transparency) }\end{array}$ \\
\hline & & & $\begin{array}{l}\text { Low (low levels of efficiency/ } \\
\text { transparency }\end{array}$ \\
\hline \multirow[t]{5}{*}{$\begin{array}{l}\text { External } \\
\text { effectiveness }\end{array}$} & $\begin{array}{l}\text { External goal } \\
\text { attainment }\end{array}$ & $\begin{array}{l}\text { Mediation } \\
\text { effectiveness }\end{array}$ & $\begin{array}{l}0 \text { to } 5 \text { scale ranging from Full } \\
\text { settlement, Settlement of major } \\
\text { conflict issues, Settlement of minor } \\
\text { conflict issues, Process agreement to } \\
\text { Ceasefire }\end{array}$ \\
\hline & $\begin{array}{l}\text { External } \\
\text { appropriateness }\end{array}$ & Good vs. harm & $\begin{array}{l}\text { High (positive contribution to } \\
\text { conflict prevention), }\end{array}$ \\
\hline & & & Medium (unclear) \\
\hline & & & $\begin{array}{l}\text { Low (negative influence on conflict } \\
\text { dynamics) }\end{array}$ \\
\hline & & Local legitimacy & $\begin{array}{l}\text { High (perceived as legitimate), } \\
\text { Medium (mixed balance) and Low } \\
\text { (perceived as illegitimate) }\end{array}$ \\
\hline
\end{tabular}

Table 1: Operationalization, own compilation based on Peen Rodt 2012; Bergmann and Niemann 2015. 


\section{Methodological Considerations}

In order to test the proposed comprehensive framework to assess mediation success this paper follows an exploratory case study design. It serves its purpose as it provides the researcher with the freedom to explore a phenomenon in the initial research phase. Explorative designs help to prepare further in-depth research and may act as a prelude to future scholarship..$^{49}$ In this paper, the framework to assess mediation success will be applied as an analytical tool to the Belgrade-Pristina Dialogue, due to the EU's heavy footprint.

Data collection was conducted as desk research relying on primary sources (such as the proceedings of the EU Council, EU commission documents, progress reports of the Governments of Serbia and Kosovo as well as opinion polls) as well as secondary sources. Those included recently published scientific articles or policy papers. As research was conducted as part of the EU-CIVCAP project,,$^{50}$ this paper also draws on first-hand information gathered during consortium partners interviews conducted in Serbia and Kosovo.

\section{Exploring the Belgrade-Pristina Dialogue}

Before delving into the analysis of the dialogue and the application of the comprehensive framework of mediation to assess success, the following chapter aims at providing a broader context. It briefly recaps the recent history of EU relations to Belgrade and Pristina since 1999 as well as between Serbia and Kosovo.

\section{Contextualizing the Dialogue}

EU-Serbia relations have been through several ups and downs since the collapse of Yugoslavia in the early 1990s and particularly after the NATO campaign in 1999 that was backed by a number of EU member states. Since then the EU has had an uneasy relation with Yugoslavia and its successor Serbia. The detention and subsequent extradition of former president Milosevic by the pro-European regime of Zoran Djindjic marked a brief episode of rapprochement that abruptly ended with the assassination of the prime minister in 2003. Despite Serbia's perceived lack of cooperation with the International Criminal Tribunal for the former Yugoslavia (ICTY), ${ }^{51}$ its recalcitrant position on the status of the Kosovo and its constant international lobbying against Kosovo's independence, the EU signed a Stabilization and Association Agreement (SSA) in 2008..$^{52}$ The signature was pushed by the EU as part of its support to the pro-Western government in the upcoming elections in order not to jeopardize Serbia's path to integration. ${ }^{53}$ However, Kosovo's dec-

49 Yin 1984.

50 Plänitz and Stojanovic Gajic 2017.

51 UN ICTY 2007.

52 Council of the European Union 2013.

53 Economides and Ker-Lindsay 2015. 
laration of independence in 2008, and Belgrade's resolute opposition to this, remained an obstacle to further progress on the path to EU accession. A new low-point in EU-Serbia relations was reached with Belgrade's decision in 2008 to question the legality of Kosovo's unilateral declaration of independence through an appeal to the International Court of Justice. ${ }^{54}$ Whilst awaiting the International Court of Justice (ICJ) decision, in 2009 Serbia submitted its application for EU membership. ${ }^{55}$ In 2010, the ICJ provided its opinion on the declaration stating that it "did not violate any applicable rule of international law". ${ }^{6}$ As an immediate response Serbia asked for a new UN General Assembly resolution for new status talks and also blocked Kosovo's participation in regional conferences. ${ }^{57}$ Faced with an EU position that clearly opposed those claims, Serbia finally accepted the EU's proposal on UN General Assembly's Resolution A/RES/64/298 that was adopted in 2010. Thereafter, Belgrade respected the ICJ ruling and accepted an EU facilitated dialogue on the normalization of relations between Serbia and Kosovo. ${ }^{58}$

Following those positive signals, the EU Council forwarded Serbia's application for EU membership to the EU Commission in October 2010. ${ }^{59}$ On March $8^{\text {th }}, 2011$, the EU facilitated dialogue between Kosovo and Serbia launched discussions on the technical level on issues such as freedom of movement and recognition of university qualifications. Although, agreements have been reached in several rounds of negotiations, the dialogue came to a halt due to violent clashes over placement of Kosovo officials at the border with Serbia in July $2011 . .^{60}$ The return to the negotiation table was accompanied by the arrest of Mladić and Hadžić. ${ }^{61}$ In response to Serbian efforts, the EU Commission recommended granting candidate status to Serbia. In its decision the EU Commission took into account the fulfilling of the Copenhagen criteria of 1993 and the prospects of ongoing BelgradePristina dialogue. ${ }^{62}$ In February 2012, Serbia received the status of official candidate for EU membership. Due to elections and a new government, the talks were interrupted in early 2012 but resumed at the end of the year as a dialogue at the political level included Prime ministers Ivica Dačić and Hashim Thaçi. On behalf of the EU HR, Catherine Ashton succeeded Robert Cooper in facilitating this dialogue. Based on several rounds of negotiations, Serbia and Kosovo signed the Brussels Agreement in April 2013 which has been widely acknowledged as a breakthrough in the mediation process. By signing the Brussels Agreement, Serbia de-facto accepted the existence of Kosovo, legitimized its

\footnotetext{
54 B92 2008.

55 European Commission 2011a.

56 International Court of Justice 2010, 1.

57 Economides and Ker-Lindsay 2015.

58 Bergmann and Niemann 2015.

59 European Commission 2011a.

60 BBC 2011.

61 Ratko Mladić and Goran Hadžić were accused of crimes against humanity and war crime by the International Criminal Tribunal for the former Yugoslavia.

62 European Commission 2011b.
} 
government and agreed to Kosovo's EU aspirations. ${ }^{63}$ Based on the Brussels Agreement, high-level talks between Belgrade, Pristina and Brussels are continuing. In May 2013, Serbia was recommended for membership talks by the EU Commission. Shortly thereafter, the Council endorsed membership talks which commenced in January 2014. ${ }^{64}$

The Belgrade-Pristina dialogue, and more particularly the changes in Serbia's policies towards the status of Kosovo, suggest that the prospect of EU membership is a considerable pull factor. In their research Bergmann and Niemann found that "enlargement is the big pull factor, the main carrot the EU has to offer"65 in the context of Serbia. For Kosovo, the second biggest carrot was visa free travel between Kosovo and the EU. However, Tamminen doubts the feasibility of the EU-membership carrot for Kosovo as existing member states are deeply divided over the question of Kosovo's independence. ${ }^{66} \mathrm{~A}$ common EU position on its status - that is not realistically to be found in the near future - is a prerequisite for serious membership negotiations, making the carrot more remote than realistic. The author also goes on to portray the position of the HR offering carrots related to EU accession or the future of the Rule of Law mission (EULEX) that she is not authorized to decide on. It is the Council who has final say in such issues. Economides and Ker-Lindsay conclude that Serbia's decision to agree on a dialogue with Kosovo and "the transformation of Serbia's policy is not because of a desire to become European in an idealized fashion, but because of the need for EU membership for realistic, practical reasons". ${ }^{67}$ Interestingly, Serbian public support for EU membership significantly dropped between 2000 and 2017, falling below 50\%, suggesting that the carrot has lost some of its pull factor. ${ }^{68}$

\section{Internal Effectiveness}

In line with the comprehensive framework introduced in this paper, the analysis of the Belgrade-Pristina dialogue begins with the assessment of internal goal attainment before examining internal appropriateness.

\section{Internal Goal Attainment}

The overall goal of the dialogue was mentioned in the "Enlargement Strategy and Main Challenges 2011-2012" document endorsed by the EU Commission stating that the EU desires negotiations "between Belgrade and Pristina to promote cooperation, achieve

\footnotetext{
63 EEAS 2013.

64 Council of the European Union 2014a.

65 Bergmann and Niemann 2015, 967.

66 Tamminen 2016.

67 Economides and Ker-Lindsay 2015, 1039.

68 Ministry of European Integration 2017.
} 
progress on the path to the EU and improve the lives of people". ${ }^{69}$ Most interestingly, EU official documents do not refer to the status of Kosovo. Hence, Serbia's recognition of Kosovo's unilaterally declared independence is not on the political agenda.

In December 2012, the General Affairs Council called for normalization between both states noting that the security and justice needs of the population in that region has to be met under a functional administration within Kosovo. ${ }^{70}$ In line with the grading scheme introduced in section three, goal attainment is graded as high. The EU as mediator achieved its major goal by establishing a process of normalization.

\section{Internal Appropriateness}

The sub-category internal appropriateness assesses the indicators efficiency and transparency as well as timing.

On the subject of efficiency and transparency, Amadio Viceré found that, despite EU member states division over the question of Kosovo's recognition as independent state ${ }^{71}$, the EU generated a "relatively consistent policy"72 in the area.

As described by Bickerton et al. (2015) the European Council in cooperation with the Foreign Affairs Council (FAC) pushed a common position that was made possible by an "ideational convergence" 73 between member states. The fact that EU member states put aside their concerns over Kosovo's independence, and instead sought a common European position for stabilizing the region, revealed a certain degree of cohesion. ${ }^{74}$ This 'unity' among EU member states, despite their divergent position on Kosovo's independence, might be a reason for leaving out a clause on Serbia's recognition of the Kosovo 'status' in the official EU goals. Formulating soft goals, such as improving citizens' lives and improving relations, facilitated support of EU members that refused Kosovo's independence.

Consensus-building is closely linked to the work of the then President of the European Council Herman van Rompuy and his efforts in agenda setting and bilateral discussions, that did not interfere with the responsibilities of FAC and the HR. As demonstrated in the negotiations towards the 2010 UN Resolution, the HR operated as an independent policy actor and has shown that she preserved the decision-making role of the Commission. ${ }^{75}$ In

69 European Commission 2011b, 27.

70 Council of the European Union 2012.

71 Spain, Greece, Slovakia, Romania and Cyprus refused to recognize Kosovo as independent state (as of 11/2016)

72 Viceré 2016, 566.

73 For an in-depth discussion see Subotić 2011.

74. Viceré 2016.

75 Ibid. 
fact, these smooth procedures have to a high degree benefited from the overlapping interests and objectives between the Council of the EU, the EU member states and the Commission. The connection of EU enlargement policies to the Common Foreign and Security Policy agenda enhanced the role of the HR in the Belgrade-Pristina dialogue. However, as Amadio Viceré notes, in cases of policy stalemate, as experienced in the aftermath of the Brussels Agreement, it is the President of European Council that takes the lead position and sidelines the HR as well as the FAC. As he puts it "in this policy field, the European Council has a clear control over the HR, the FAC and the same Commission since it is the only institution able to reduce the risk of shirking". ${ }^{76}$

When exploring the political cost of dialogue for the EU, the recent establishment of post-Lisbon institutions must be taken into account. The newly founded European Union External Action (EEAS) and the new EU 'Foreign Minister' role of were mandated and equipped to approach the situation as they appeared in 2011 between Serbia and Kosovo. Facilitating dialogue is a core competency of the institution and the Belgrade-Pristina talks were a litmus test, since political failure would have questioned the effectiveness and assertiveness of the EEAS and the HR. Still engaged in its own institution-building and bearing the burden of mixed results of previous mediation efforts in the region, ${ }^{77}$ the political risk can be rated as considerable. Taking into account this high risk, the low financial footprint of dialogue facilitation (compared to other means of conflict resolution) and high level of goal attainment, the variable internal effectiveness can be rated as high.

Considering transparency of the mediation process, recent empirical material suggests that local NGOs perceive a significant lack of EU communication which then hampers their involvement. The strategic ambiguity of the agreements that were initially beneficial have now turned into a "barrier to demanding accountability from the elites regarding the lack of implementation of agreements". ${ }^{78}$ For local NGOs it also seems to be unclear which role the EU takes in the mediation. Local civil society representatives have argued that when there is success, the EU claims to be a mediator. In times of failure, the EU returns to the position of a facilitator. Regarding internal transparency, interviewees claimed that there is a need for better coordination between EEAS HQ, the EU's presence in the field and its member states. It is also hinted that the EEAS is perceived as understaffed - making it impossible for an individual at EEAS to cope with the tasks.

To sum up, the mediation process can be characterized as highly efficient in terms of coherence and cost effectiveness. Despite disputes among EU member states on the status of Kosovo, EU institutions worked together towards the goal of the dialogue. However, the research suggests that considerable problems exist with regard to internal and external transparency. As transparency issues did not hinder the negotiations as such, but local implementation, this measure is rated as medium.

76 Ibid., 567.

77 Bieber 2015.

78 Plänitz and Stojanović Gajić 2017, 54. 
Regarding the timing of the mediation, it needs to be noted that relations between Belgrade and Pristina had already had a history of violence and diplomatic conflict when the EU facilitated dialogue launched in 2011. Emerging from the war that ended in 1999, Kosovo was put under UN administration in accordance with UN Security Council Resolution $1244 .{ }^{79}$ As foreseen in UN Resolution 1244, and recommended by Kai Eide's report in $2005,{ }^{80}$ the United Nations facilitated status talks began in 2006. Led by UN Special Envoy Martti Ahtisaari, both conflict parties failed to reach an agreement on the future status of Kosovo. However, whilst the Ahtisaari Plan noted the right to adopt a constitution, create an army and seek membership of international organizations, it avoided mentioning the term "independence". Nevertheless, in 2007, 225 out of 244 members of Serbia's parliament voted against the Ahtisaari Plan. ${ }^{81}$ Realizing that the Plan would not receive backing from Russia - after having presented four drafts to the UN Security Council - the process was put on hold in July 2007. ${ }^{82}$ The following consultations of the 'Troika' (EU, USA and Russia) also failed to reach an agreement on the status of Kosovo in December 2007. ${ }^{83}$ On 17 February 2008, Kosovo finally declared its independence from Serbia. Belgrade strongly opposed this decision but stated that it would not react violently. ${ }^{84}$ In October 2008, at the request of Serbia, the General Assembly of the United Nations sought legal advice from the ICJ regarding the declaration of independence. However, the decision of Pristina sparked a series of unrest in its Northern territories mainly inhabited by Kosovo-Serbs provoking a response by UN police and NATO.

After having briefly recalled post-1999 relations between the EU, Kosovo and Serbia, this paper takes a closer look at the motivations and domestic policies at the time of the launch of the dialogue in 2011.

With the opinion of the ICJ in 2010 concluding that Kosovo's declaration of independence did not infringe international law, Belgrade had exhausted almost all possible juridical avenues to annul Kosovo's decision. Having excluded the path of violence to roll back Pristina's declaration, a political dialogue was the only option left to the Serbian government. Moreover, given Serbia had applied for EU membership on 22 December 2009 and although, the then President of the European Commission Barroso did not explicitly state that Belgrade's recognition of Kosovo's independence was a prerequisite for membership, he noted that normalization of the relationship between both capitals was needed. Accordingly, Barroso argued that Belgrade's position on Kosovo would be taken into account when processing Serbia's application. ${ }^{85}$ The EU Commissioner for Enlargement at

\footnotetext{
79 UN Security Council 1999.

80 Secretary-General 2005.

81 DW 2007.

82 Phillips 2012, 169.

83 Spörl2007.

84 CNN 2008.

85 B92 2011.
} 
the time, Stefan Füle, reiterated that argumentation stating that 'normalization' was required, not 'recognition.'s6

The Government of Kosovo can be described as less enthusiastic, although the dispute with Serbia had noticeable impact on the economic situation, telecommunication and freedom of travel. ${ }^{87}$ However, Pristina was more skeptical about the EU's neutrality as not all member states had acknowledged Kosovo's independence. Moreover, a political dialogue on the status of the Kosovo-Serbs was considered a 'domestic issue' that should not be part of the negotiations. ${ }^{88}$ In addition, the EU has not had the pull factor of a prospective membership as this was considered out of reach at that time. ${ }^{89}$ The Pristina Government was more interested in a 'seat at the table' within the international community. Kosovo Prime Minister Hashim Thaçi argued that "reciprocal recognition between Kosovo and Serbia [...] will facilitate quick and necessary integrations toward Euro-Atlantic structures". 90 This position has been backed by the "Resolution for dialogue between Kosovo and Serbia' adopted by the Assembly of Republic of Kosovo stating that the dialogue should contribute to "regional cooperation, good neighboring relations and the dialogue shall contribute the peace, stability and economic development of our countries and the region in general as well as the acceleration to European and Euro-Atlantic integration". ${ }^{91}$

To sum up, the study on the context of the dialogue in terms of both the chronology of the relations between Serbia and Kosovo and the motivation to accept mediation suggest that a mutual hurting stalemate (MHS) had been reached. Coming from a war that ended in 1999, going through a UN facilitated dialogue without reaching an agreement, and finally the legal advice of the ICJ, demonstrate that most opportunities of conflict settlement had already been exhausted. According to Zartman, Serbia and Kosovo found the conflict parties were found in a situation without any prospects of achieving success. Thus, the painful deadlock for Serbia and Kosovo urged them to seek alternative solutions. ${ }^{92}$ For Serbia, it was clear that without solving the Kosovo 'issue' EU membership was unrealistic. Although, dialogue was of less urgence to Kosovo than it was to Serbia, Pristina had an interest in an international integration that might be facilitated by the mediation. Therefore, timing is considered to be low as a deadlock was reached prior to accepting mediation.

\footnotetext{
86 Balkan Insight 2012.

87 Balkan Investigative Reporting Network, Internews Kosova, and Centre for Research Transparency and Accountability 2014.

88 Hamilton 2012.

89 Bieber 2015.

90 Radio Free Europe 2011.

91 Assembly of the Republic of Kosovo 2011.

92 Zartman 2001.
} 


\section{External Effectiveness}

The category of external effectiveness aims at taking a conflict based perspective studying both appropriateness and goal attainment. This section collectively reviews the subsequent indicators of local legitimacy, good vs. harm and mediation effectiveness.

\section{Local Legitimacy}

As noted earlier, the Belgrade-Pristina dialogue has been conducted at high-level involving prime ministers of both Serbia and Kosovo. This has not come without impact upon local perceptions of those mediation efforts. After having interviewed members of Kosovo NGO's, Randazzo concluded that the dialogue "has so far not served the purpose of reaching everyday lives of people in Kosovo" ${ }^{93}$ Although, a survey among Kosovo citizens by the Kosovar Center for Security Studies (KCSS) revealed that there is a narrow majority of Kosovo citizens in favor of those negotiations, $38 \%$ do not support the dialogue. Moreover, of the non-supporters, $28 \%$ believed negotiations should be stopped immediately." 94 However, public support for the dialogue among citizens of Serbia seems to be higher. The Belgrade Centre for Security Policy found that the respondents "support the agreements with Pristina as long as it does not lead to the recognition of Kosovo.". ${ }^{95}$ Furthermore, only 9\% are against these talks. ${ }^{96}$ According to the EU-CIVCAP report, the EU had not considered the lack of inclusiveness as a problem in the normalization process. Moreover, its sole engagement with the ruling elites of Kosovo and Serbia engendered criticism within the local community. Facilitating mediation that is perceived as elite captured is associated with a debate on local spoilers. Accordingly, "the EU is discussing with the main spoilers of dialogue, while letting civil society mediate the inter-ethnic relations" ${ }^{97}$

Based on the results presented here, the measure for local legitimacy can be rated as low. The evidence suggests that the mediation process is perceived as 'elite-captured. Opinion polls fail to demonstrate large public support for the dialogue among citizens in Kosovo.

\section{Good vs. Harm and Mediation Effectiveness}

While having achieved the overall goal of Serbia's de facto recognition of Kosovo's independence, the Brussels Agreement and the dialogue has so far not settled all disputes at the local level. The Serb attacks on KFOR troops in Northern territories of Kosovo in relation to an attempt by Kosovo authorities to man a border post in 2011 unveiled re-

93 Randazzo 2017, 135.

94 Kosovar Center for Security Studies 2015, 14.

95 Popović 2017.

96 Ibid.

97 Plänitz and Stojanović Gajić 2017, 45. 
maining hostilities in the region. ${ }^{98}$ The clashes shed light on the situation in the Northern territories of Kosovo that is composed of four Serb-majority municipalities. Since its formal independence, Kosovo authorities failed to extend their influence into the region that rejects the existence of an independent Kosovo state. Only recently has this changed with Kosovo institutions (e.g. Court) gradually gaining influence in the north.

Prior to the 2013 Brussels Agreement, in an informal referendum organized in the Northern territories on the acceptance of Kosovo's authorities, 99\% of the respondents said "no, we would not accept it".99 Officially, the Brussels Agreement foresees Belgrade's acceptance that Northern territories are part of Kosovo and that Pristina's commits to safeguard the interests of local Serbs in the region. In 2015, a second agreement translated the Brussels accords into practical implementation. The most controversial part of the negotiated agreement is the installation of a coordination body in the Northern territories that represents the Serb-municipalities. Due to the double-wording in the final document ("association/community") Kosovo interprets the body as an NGO with limited responsibilities whereas Serbia insists on it being a constitutional organ. Furthermore, the agreement sparked considerable opposition in Kosovo and led to internal political deadlock. According to Capussela, the situation could easily escalate and turn into social unrest. The appraisal of a general dissatisfaction has been backed by an opinion poll conducted by the KCSS. Asked about the constitution of Serb Majority Municipalities, $78 \%$ of the respondents considered it very harmful or harmful. ${ }^{100}$

Indeed, these developments suggest that the agreement has been reached "not with the region, but about the region". ${ }^{101}$ The citizens of the Northern territories of Kosovo were not involved in the negotiations on their future status thus risking the perception that the agreement is illegitimate on the ground. ${ }^{102}$ The negotiations might have opened Pandora's Box as it is infringing the status quo of the Northern territories. Before the agreement, Kosovo's authorities made no attempt to extend their reach up to the North, and Phillips argues that part of the administration even welcomed a separation. ${ }^{103}$ Moreover, criminal circles allegedly connected to the political elite benefitted from Northern Kosovo's unclear status. On the other hand, Serbia's interest in annexing the Northern territories seemed to be limited due to the fact that Belgrade has nothing to provide in exchange. ${ }^{104}$

However, this rather negative picture changes when taking the position of Kosovo-Serb population. According to Ejdus, the Brussels Agreement provided for the first time "a more

\footnotetext{
98 Reuters 2011.

99 Capussela 2016, 183.

100 Kosovar Center for Security Studies 2017, 32.

101 Economides and Ker-Lindsay 2015, 1035.

102 Capussela 2016; Economides and Ker-Lindsay 2015; Ernst 2014.

103 Phillips 2014.
}

104. Capussela 2016. 
realistic, sustainable and orderly perspective" 105 for Serb citizens living in the Serb municipalities. Furthermore, the Brussels Agreement foresaw the integration of the predominantly Serb police forces in Kosovo Northern territories into the Kosovo security/justice state structures. as well as municipal elections to be held in November 2013. Apart from minor incidents, for example in Kosovska Mitrovica, the ballot took place peacefully. In addition, agreements on telecommunications, energy, customs stamps, university qualifications, freedom of movement of Integrated Border Management (IBM) have been implemented successfully or are on track with minor discrepancies between the conflict parties. ${ }^{106}$

Despite the significant progress in some areas, the wording in recent status reports of both Serbian and Kosovo ministries paint a clear picture of mutual mistrust. In its 2017 report, Serbia accused Pristina of "blackmailing"107 and alleged a "lack of political will"108 - an accusation that was then returned by Kosovo. ${ }^{109}$ Moreover, Pristina blamed Belgrade of "dualism in implementation" 110 arguing that agreements are implemented by Serbia whilst not refraining from supporting parallel structures in Kosovo's Northern territories. Those allegations are just a small sample, but illustrate the long way still to go to achieve normalization and mutual trust between Kosovo and Serbia.

Looking at the development of conflict in the region related to the Kosovo-Serbian relations from 1999 to 2015, demonstrates the uneasy relationship between Kosovo and Serbia as well as Kosovo and its Northern territories. According to data from the Heidelberg Conflict Barometer, ${ }^{111}$ the level of intensity surrounding the Kosovo status issue decreased from 3 ('Violent Crisis') to 1 ('Dispute') during the dialogue between Belgrade and Pristina. On the other hand, two new conflicts appeared in 2013 and 2015. In 2013 violent clashes between Kosovo-Serbs and security forces in the Northern territories occurred. In 2015, the database recorded a category 3 ('Violent Crisis') conflict between the Kosovo Government and the Vetevendosje opposition group. Protests against an agreement reached during the Belgrade-Pristina dialogue delegating greater administrative powers to the Kosovar Serb majority municipalities, turned violent in early 2015 (Figure 2 ). Reoccurring clashes between protesters and security forces left dozens injured. The Kosovo Police Force recorded a total number of 99 attacks on cultural heritage sites in 2015 - including Islamic, Orthodox and Catholic religious sites. This figure was up from 88 incidents recorded in 2014. ${ }^{112}$ On Kosovo-Serb cross-border clashes, Demjaha con-

105 Ejdus 2014, 6.

106 Ibid.

107 Office for Kosovo and Metohija and Office for the Coordination of Affairs in the Process of Negotiation with the Provisional Institutions of Self-Government in Pristina 2017, 27.

108 Ibid.

109 Ministry for Dialogue 2016.

110 Ibid., 87.

111 Datasets and reports from the Heidelberg Conflict Barometer obtained at https://www.hiik.de/ en/konfliktbarometer/index.php.

112 Kosovo Police 2015. 
cluded that tensions between Kosovo and Serbia have increased to "alarming levels" ${ }^{113}$ Apart from the already mentioned protests, he refers to the wall build by Serb authorities in Mitrovica and the train that has been sent from Belgrade to northern Mitrovica but never entered Kosovo, decorated with nationalist slogans. The assassination of the Kosovo-Serb politician Oliver Ivanovic ${ }^{114}$ and the arrest of Marko Djuric, the head of the Serbian Governments Office for Kosovo in Mitrovica ${ }^{115}$ in 2018 further jeopardized the rapprochement process. Those incidents undermine any attempt to ease inter-ethnic tensions between Kosovo-Albanians and Kosovo-Serbs.

\section{Conflicts related to Kosovo and Serbia between 1999 and 2015}

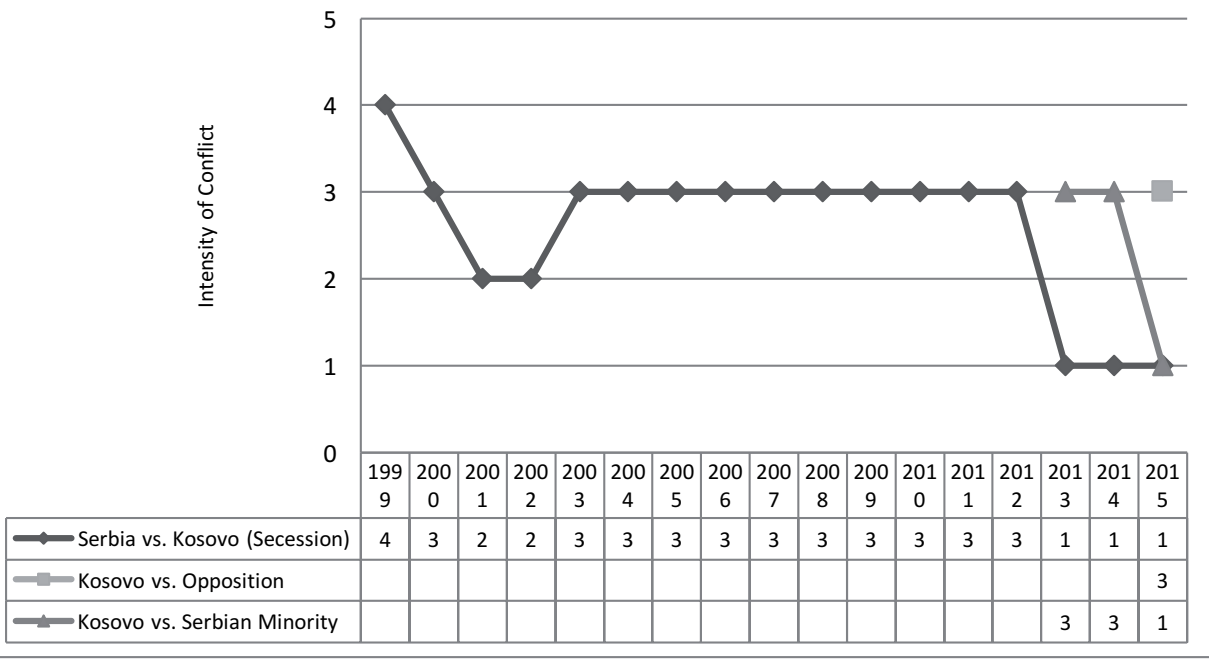

Figure 2: Development of Conflicts related to Kosovo and Serbia between 1999 and 2015, based on the Heidelberg Conflict Barometer. Due to a change in rating criteria and conflict scale in 2003, comparability to data prior to 2003 is only limited.

Ernst noted that the 'vaguely defined agreement' in terms of the status of the Northern territories was reached with the intention to demonstrate success. ${ }^{116}$ However, it is worth mentioning that the concept of ambiguities is considered a common strategy in peace negotiations. Pehar argued that despite several examples of hostilities re-igniting, ambiguities may provide the only bridge between involved parties. ${ }^{117}$ Even if assuming that this vague agreement was set up intentionally, it failed to serve its purpose. Commenting on

113 Demjaha 2017, 182.

114 BBC 2018.

115 EURACTIV 2018.

116 Ernst 2014.

117 Pehar 2001. 
the mediation strategy, Bieber found that the creative ambiguity approach yielded results, but left room for misinterpretations. ${ }^{118}$

Both, Belgrade and Pristina had chosen not to further jeopardize their EU aspirations. In addition, due to the weak economic situation in their countries, both governments used the agreement to generate legitimacy by claiming a diplomatic success. Catherine Ashton, the then HR, was keen to showcase the Brussels Agreement, to enhance her record as High Representative of the Union for Foreign Affairs and Security Policy. ${ }^{119}$ A hint that the EU institutions had started to acknowledge the weakness of the Brussels Agreement was given in the Joint Communication, which labelled the Belgrade-Pristina dialogue as "pragmatic", ${ }^{120}$ avoiding the enthusiastic wording used in 2013 and 2014 - which referred to it as a "landmark agreement"121 and "historic breakthrough".122

\section{Conclusion}

The paper introduced a comprehensive framework to assess mediation success that enhances existing approaches to measure "success". It is characterized by taking both internal and external perspectives into account with respect to local perceptions. Application of the framework to the Belgrade-Pristina dialogue underlined its promising character. While previous studies have been limited to either mediators' effectiveness or solely judged the mediation outcome, this paper examines the role of the EU and its internal procedures as well as the mediation outcome and its consequences at the local level. The application of the comprehensive framework revealed the mixed results of the Belgrade-Pristina dialogue. While being an internationally recognized success for the HR and EEAS, the Brussels Agreement failed to significantly contribute to sustainable peace in Kosovo's Northern territories. Although, some major protocols signed during the negotiations have been put into practice and have started to improve the everyday life of the citizens in Kosovo's Northern territories, a complete settlement of the conflict is dependent upon ongoing negotiations and the further implementation of the agreements already reached. Whereas the conflict intensity between Kosovo and Serbia has reduced since 2011, domestic conflicts in Kosovo have increased.

Considering internal effectiveness, the Belgrade-Pristina dialogue has been mainly coordinated by the HR and backed by the EEAS. The leading role of the HR in the process has been facilitated by the unified EU goal of ensuring peace in Europe's backyard. Although, there is considerable dissent concerning the status of Kosovo amongst EU member states, the dialogue has received support from the Council and EU foreign ministers that have

118 Bieber 2015.

119 Ernst 2014.

120 European Commission 2016.

121 Council of the European Union 2014b, 8.

122 Ibid. 
been visiting the region regularly encouraging both conflict parties to remain committed. Therefore, coherence and internal appropriateness can be rated as high. However, using the carrot of EU membership with Kosovo without having clear prospects may undermine the EU's credibility at a later stage. Assessing the EU facilitated dialogue through the lens of internal goal attainment reveals a rather bright picture. An agreement was signed in Brussels that includes EU membership prospects, is clear on administrational and institutional arrangements in Kosovo's Northern territories and achieved a normalization of relations between the states. Without a doubt, the rapprochement process between Serbia and Kosovo can be regarded as a success. Looking at this variable in an isolated way it can be rated as high as most or even all of the goals have been achieved in the dialogue. However, when broadening the view to external effectiveness and the outcome of the mediation efforts, the result looks quite different. While the status of implementation of some agreements looks promising - being either already implemented or on track - the impression changes when scratching the surface of the Brussels Agreement considering the situation on the ground. It is obvious that there is still a long way to go until a total normalization of relations is achieved.

The perceived exclusion of Kosovo Serbs and Kosovar civil society from the negotiations combined with widespread poverty and missing economic prospects is a feeding ground for further social unrest that potentially threatens progress made in the dialogue. According to the Bergmann and Niemann scale (2015), mediation effectiveness can be rated between 3 and 4, as some conflict issues have been settled but there is substantial work left. Following the argumentations of Capussela (2016), Phillips (2014) and Ernst (2014) the Brussels Agreement challenged the status quo of Kosovo's Northern territories. At the micro-level the agreement tends to have a medium to low influence on the conflict dynamics in the short-run.

Studying the domestic situation within Kosovo revealed that during the course of the dialogue between Belgrade and Pristina the security situation worsened. Data from the Heidelberg Conflict Barometer suggest that from 2012, local, intra-Kosovo conflicts have appeared that are directly related to the outcome of the dialogue. Overall, the case study proved the argumentation of Gartner (2014) and Beardsley (2011) on the duration of directive mediation strategies. Accordingly, choosing a directive mediation strategy by offering strong incentives (EU perspective) led to a quick agreement with limited durability.

Future research on mediation efforts may expand the comprehensive framework to assess mediation success towards local perceptions towards a negotiated peace agreement. ${ }^{123}$ While the part of the local population in this paper was only considered as a side factor, it should play a more prominent role in future development of the approach. This is strongly linked to the academic debates about peace spoilers and local legitimacy. Incorporating a stronger bottom-up perspective may contribute to more robust results and assessments.

123 For a recent discussion of the role of local in EU peacebuilding see Ejdus and Juncos 2018. 


\section{References}

Amadio Viceré, Maria Giulia. 2016. “The roles of the President of the European Council and the High Representative in leading EU foreign policy on Kosovo." Journal of European Integration 38 (5): 557-570.

Assembly of the Republic of Kosovo. 2011. "Resolution-For dialogue between Republic of Kosovo and Republic of Serbia”.

Balkan Insight. 2012. “EU: Serbia Does Not Have to Recognize Kosovo”. Accessed January 12, 2017. http://www.balkaninsight.com/en/article/eu-does-not-requestserbia-to-recognize-kosovo.

Balkan Investigative Reporting Network, Internews Kosova, and Centre for Research Transparency and Accountability. 2014. "Big Deal - Civic Oversight of the KosovoSerbia Agreement Implementation".

BBC. 2011. "Kosovo tense after deadly clash on Serbian border". Accessed January 12, 2017. http://www.bbc.com/news/world-europe-14303165.

BBC. 2018. “Top Kosovo Serb politician Oliver Ivanovic shot dead”. Accessed March 27, 2018. http://www.bbc.com/news/world-europe-42701712.

Beardsley, Kyle. 2006. "Mediation Style and Crisis Outcomes." Journal of Conflict Resolution 50 (1): 58-86.

Beardsley, Kyle. 2011. The Mediation Dilemma. Ithaca: Cornell University Press.

Beha, Adem. 2015. "Disputes over the 15-point agreement on normalization of relations between Kosovo and Serbia.” Nationalities Papers 43(1): 102-121.

Bercovitch, Jacob, Theodore Anagnoson, and Donnette Wille. 1991. "Some Conceptual Issues and Empirical Trends in the Study of Successful Mediation in International Relations." Journal of Peace Research 28 (1): 7-17.

Bercovitch, Jacob, and Gerald Schneider. 2000. "Who Mediates? The Political Economy of International Conflict Management." Journal of Peace Research 37 (2): $145-165$.

Bercovitch, Jacob. 2006. "Mediation success or failure: The search for the elusive criteria." Cardozo Journal of Conflict Resolution 7 (2): 289-302. 
Bercovitch, Jacob, and Karl DeRouen. 2004. "Mediation in Internationalized Ethnic Conflicts: Assessing the Determinants of a Successful Process." Armed Forces $\mathcal{E}$ Society 30 (2): 147-170.

Bercovitch, Jacob, and Paul F. Diehl. 1997. "Conflict management of enduring rivalries: The frequency, timing, and short-term impact of mediation." International Interactions 22 (4): 299-320.

Bercovitch, Jacob, and Judith Fretter. 2004. Regional guide to international conflict and management from 1945 to 2003. Washington, D.C: CQ Press.

Bercovitch, Jacob, and Richard Jackson. 2009. Conflict resolution in the twenty-first century: principles, methods, and approaches. Ann Arbor: University of Michigan Press.

Bercovitch, Jacob, and Scott Sigmund Gartner. 2006. "Is There Method in the Madness of Mediation? Some Lessons for Mediators from Quantitative Studies of Mediation." International Interactions 32 (4): 329-354.

Bergmann, Julian, and Arne Niemann. 2015. "Mediating International Conflicts: The European Union as an Effective Peacemaker?: The EU as mediator in international conflicts." JCMS: Journal of Common Market Studies 53 (5): 957-975.

Bickerton, Christopher J., Dermot Hodson, and Uwe Puetter. 2015. „The New Intergovernmentalism: European Integration in the Post-Maastricht Era: The new intergovernmentalism." JCMS: Journal of Common Market Studies 53(4): 703-722.

Bieber, Florian. 2015. “The Serbia-Kosovo Agreements: An EU Success Story?” Review of Central and East European Law 40(3-4): 285-319.

Böhmelt, Tobias. 2011. "Disaggregating Mediations: The Impact of Multiparty Mediation." British Journal of Political Science 41 (04): 859-881.

Brandenburg, Natalie C. 2017. "EU Mediation as an Assemblage of Practices: Introducing a New Approach to the Study of EU Conflict Resolution: Assembling EU mediation." JCMS: Journal of Common Market Studies 55 (5): 993-1008.

B92. 2008. "ICJ move direct challenge to EU”. Accessed January 12, 2017. http://www. b92.net/eng/news/politics.php?yyy=2008\&mm=08\&dd=03\&nav_id=52409.

B92. 2011. "Kosovo recognition 'not condition for integrations". Accessed January 12, 2017. http://www.b92.net/eng/news/politics.php?yyyy=2011\&mm=05\&dd=20\&nav_ $\mathrm{id}=74433$. 
Capussela, Andrea Lorenzo. 2016. "Kosovo: Political Evolution and the Negotiations with Serbia."IEMed. Mediterranean Yearbook 2016: 182-185.

CNN. 2008. "Kosovo celebrates amid Serb protests". CNN, 2008. Accessed January 12, 2017. http://edition.cnn.com/2008/WORLD/europe/02/17/kosovo. independence/.

Council of the European Union. 2013. "Council and Commission Decision of 22 July on the conclusion of the Stabilisation and Association Agreement between the European Communities and their Member States of the one part, and the Republic of Serbia, of the other part." Official Journal of the European Union, L278/14.

Council of the European Union. 2012. 3210th Council meeting "General Affairs". Press Release. Brussels.

Council of the European Union. 2014a. "First Accession Conference with Serbia."

Council of the European Union. 2014b. "Main aspects and basic choices of the CFSP" (Part II, point E, paragraph 25 of the Interinstitutional Agreement of 2 December 2013) - 2013 - Annual report from the High Representative of the European Union for Foreign Affairs and Security Policy to the European Parliament.

Davis, Laura. 2014. EU foreign policy, transitional justice and mediation: principle, policy and practice. London, New York: Routledge.

Demjaha, Agon. 2017. “Inter-Ethnic Relations in Kosovo."SEEU Review 12 (1): 181-196.

Diehl, Paul F., and Gary Goertz. 2000. War and peace in international rivalry. Ann Arbor: University Of Michigan Press.

DW. 2007. “Serbia Rejects UN Plan for Kosovo”. Accessed January 12, 2017. http:// www.dw.com/en/serbia-rejects-un-plan-for-kosovo/a-2351650.

Economides, Spyros, and James Ker-Lindsay. 2015. “Pre-Accession Europeanization': The Case of Serbia and Kosovo: Pre-Accession Europeanization." JCMS: Journal of Common Market Studies 53 (5): 1027-1044.

Edmead, Frank. 1971. Analysis and prediction in international mediation. New York: United Nations Institute for training and Research.

EEAS. 2013. "Serbia and Kosovo reach landmark deal”. 
Ejdus, Filip. 2014. The Brussels Agreement and Serbia 's National Interests: A Positive Balance Sheet? Belgrade: Konrad Adenauer Stiftung.

Ejdus, Filip, and Ana E. Juncos. 2018. "Reclaiming the local in EU peacebuilding:

Effectiveness, ownership, and resistance." Contemporary Security Policy 39 (1): 4-27.

Ernst, Andreas. 2014. "The April Agreement - A Step towards Normalization

between Belgrade and Pristina?" Contemporary Southeastern Europe 1(1): 122-124.

EURACTIV 2018. “Tensions as Kosovo police arrest senior Serbian official”. Accessed March 28, 2018. https://www.euractiv.com/section/enlargement/news/tensions-askosovo-police-arrest-senior-serbian-official.

European Commission. 2011a. “Commission Opinion on Serbia's application for membership of the European Union".

--. 2011b. "Enlargement Strategy and Main Challenges 2011-2012".

--. 2016. “Towards an EU strategy for international cultural relations”.

Frazier, Derrick V., and William J. Dixon. 2006. "Third-Party Intermediaries and Negotiated Settlements, 1946-2000.” International Interactions 32(4): 385-408.

Frei, Daniel. 1976. "Conditions affecting the effectiveness of mediation." Peace Science Society (International) Papers (26): 67-84.

Gartner, Scott Sigmund. 2014. “The Influence of Directive Strategies on Settlement Duration." International Negotiation 19(2): 201-220.

Gashi, Krenar, Vjosa Musliu, and Jan Orbie. 2017. "Mediation Through Recontextualization: The European Union and The Dialogue Between Kosovo and Serbia." European Foreign Affairs Review 22 (4): 33-50.

Girke, Natalie C. 2015. "A matter of balance: the European Union as a mediator in Yemen." European Security 24 (4): 509-524.

Hamilton, Aubrey. 2012. From Technical Agreements to Political Haggling: The Kosovo-Serbia Dialogue and the North of Kosovo. Pristina: Group for Legal and Political Studies.

Heidelberg Institute for International Conflict Research (HIIK). 1999. Conflict Barometer 1999 - 2015. Conflict Barometer. Heidelberg: University of Heidelberg. 
Hill, Christopher, and Karen Elizabeth Smith. 2000. European foreign policy: key documents. London, New York: Routledge.

International Court of Justice. 2010. "Accordance with international law of the unilateral declaration of independence in respect of Kosovo - Advisory Opinion." The Hague: International Court of Justice.

Jarstad, Anna, and Timothy D. Sisk, eds. 2008. From war to democracy: dilemmas of peacebuilding. Cambridge: Cambridge University Press.

Katz Jameson, Jessica. 1999. "Toward A Comprehensive Model For The Assessment Of Intraorganizational Conflict: Developing The Framework." International Journal of Conflict Management 10 (3): 268-294.

Kleiboer, Marieke. 1996. "Understanding Success and Failure of International Mediation." Journal of Conflict Resolution 40 (2): 360-389.

Kosovar Center for Security Studies. 2015. "Public Perceptions on Kosovo's Foreign Policy and Political Dialogue with Serbia - Kosovo Security Barometer." Pristina: Kosovar Center for Security Studies.

--. 2017. "Kosovo Security Barometer: Trends of Perception towards Kosovo's Foreign Policy and Dialogue with Serbia - Covering period from 2013 - 2016." Pristina: Kosovar Center for Security Studies.

Kosovo Police. 2015. "Annual Report 2015." Policia e Kosovës / Drejtoria për Planifikim Strategjik dhe Çështje Ligjore.

Kriesberg, Louis, and Stuart J. Thorson, eds. 1991. Timing the de-escalation of international conflicts. Got ed. Syracuse studies on peace and conflict resolution. Syracuse, N.Y: Syracuse University Press.

Maundi, Mohammed Omar, ed. 2006. Getting in: mediators' entry into the settlement of African conflicts. Washington, D.C: United States Institute of Peace Press.

Michael Greig, J., and Patrick M. Regan. 2008. "When Do They Say Yes? An Analysis of the Willingness to Offer and Accept Mediation in Civil Wars." International Studies Quarterly 52 (4): 759-781.

Ministry for Dialogue. 2016. "Brussels Agreements - Implementation State of Play 16 June - 25 November 2016." Pristina: Republic of Kosovo. 
Ministry of European Integration. 2017. "Public Opinion Poll: European Orientation of Serbian Citizens" (June 2017). Belgrade.

Nathan, Laurie. 1999. “'When Push Comes to Shove': The Failure of International Mediation in African Civil Wars." Track Two: Constructive Approaches to Community and Political Conflict 8 (2).

Nilsson, Desirée. 2012. "Anchoring the Peace: Civil Society Actors in Peace Accords and Durable Peace."International Interactions 38(2): 243-266.

Office for Kosovo and Metohija and Office for the Coordination of Affairs in the Process of Negotiation with the Provisional Institutions of Self-Government in Pristina. 2017. "Progress Report on the Dialogue between Belgrade and Pristina (October 2016 - April 2017)." Belgrade: Government of the Republic of Serbia.

Peen Rodt, Annemarie. 2012. "EU Performance in Military Conflict Management." In the European Union as a Global Conflict Manager, edited by R.G. Whitman and S. Wolff, 169-188. London: Routledge.

Pehar, Drazen. 2001. "Use of ambiguities in peace agreements." In Language and Diplomacy, edited by J. Kurbalija and H. Slavik, 163-200. Malta: DiploProjects.

Phillips, David L. 2012. Liberating Kosovo: coercive diplomacy and U.S. intervention. Cambridge, MA: MIT Press.

Plänitz, Erik, and Sonja Stojanovic Gajic. 2017. "Report on impact of EU engagement on mediation and local level dialogue initiatives in Western Balkans." Deliverable 5.2. EU - CIVCAP.

Popović, Miloš. 2017. "Public Opinion on the Security of Serbia and Dialogue with Pristina." Belgrade: Centre for Security Policy.

Pushkina, Darya. 2006. "A recipe for success? Ingredients of a successful peacekeeping mission." International Peacekeeping 13 (2): 133-149.

Radio Free Europe. 2011. "Kosovo Leader Hashim Thaci: NATO Intervention 'Was the Only Righteous and Humane Solution”. Accessed January 12, 2017. http:// www.rferl.org/a/kosovo_leader_thaci_intervention_was_the_only_righteous_and_ humane_solution/3538318.html.

Randazzo, Elisa. 2017. Beyond liberal peacebuilding: a critical exploration of the local turn. Abingdon, Oxon, New York: Routledge. 
Regan, Patrick M., and Aysegul Aydin. 2006. "Diplomacy and Other Forms of Intervention in Civil Wars." Journal of Conflict Resolution 50(5): 736-756.

Regan, Patrick M., and Allan C. Stam. 2000. "In the Nick of Time: Conflict Management, Mediation Timing, and the Duration of Interstate Disputes." International Studies Quarterly 44(2): 239-260.

Reuters. 2011. "Ethnic Serbs fire at NATO troops in Kosovo”. Accessed January 12, 2017. http://www.reuters.com/article/kosovo-nato-idUSBYT76945420110727.

Savun, Burcu. 2008. "Information, Bias, and Mediation Success." International Studies Quarterly 52 (1): 25-47.

Secretary General. 2005. Letter dated 7 October 2005 from the Secretary-General addressed to the President of the Security Council.

Sheppard, Blair. 1984. "Third party conflict intervention: A procedural framework." Research in Organizational Behavior 6: 141-190.

Smith, William P. 1985. "Effectiveness of the Biased Mediator." Negotiation Journal 1 (4): 363-372.

Spörl, Gerhard. 2007. "The Kosovo Failure - Mission Impossible in the Balkans". Spiegel Online. Accessed January 12, 2017. http://www.spiegel.de/international/ europe/the-kosovo-failure-mission-impossible-in-the-balkans-a-522406.html

Subotić, Jelena. 2011. "Europe is a State of Mind: Identity and Europeanization in the Balkans.” International Studies Quarterly 55 (2): 309-330.

Tamminen, Tanja. 2016. "Challenges: EU Civilian Crisis Management and the Objective of Impact Assessment-Kosovo as an Example of Complexity." In Complexity thinking for peacebuilding practice and evaluation, edited by Emery Brusset, Cedric De Coning, and Bryn W Hughes, 111-139. UK: Palgrave.

Touval, Saadia. 2003. "Mediation and Foreign Policy." International Studies Review 5 (4): $91-95$.

Touval, Saadia, and I. William Zartman, eds. 1985. International mediation in theory and practice. SAIS papers in international affairs No. 6. Boulder: Washington, D.C: Westview Press, Foreign Policy Institute, School of Advanced International Studies, Johns Hopkins University. 
UN ICTY. 2007. "Prosecutor's statement on Serbia's cooperation with her office." The Hague: International Criminal Tribunal for the former Yugoslavia.

UN Security Council. "Security Council resolution 1244 [on the deployment of international civil and security presences in Kosovo]” S/RES/1244 (1999).

Visoka, Gëzim. 2017. “Peace as Normalisation.” In Shaping Peace in Kosovo: The Politics of Peacebuilding and Statehood, edited by Gëzim Visoka, 183-219. Cham: Springer International Publishing.

Vuković, Siniša. 2014. "International mediation as a distinct form of conflict management." International Journal of Conflict Management 25 (1): 61-80.

Wall, James A., Rhetta L. Standifer, and John B. Stark. 2001. "Mediation: A Current Review and Theory Development." The Journal of Conflict Resolution 45 (3): 370-391.

Wallensteen, Peter, and Isak Svensson. 2014. "Talking peace: International mediation in armed conflicts." Journal of Peace Research 51 (2): 315-327.

Wilkenfeld, Jonathan; Kathleen Young; Victor Asal, and David Quinn. 2003. "Mediating International Crises: Cross-National and Experimental Perspectives." Journal of Conflict Resolution 47 (3): 279-301.

Yin, Robert K. 1984. Case study research: design and methods. Thousand Oaks: Sage Publications.

Zartman, I William. 2001. "The timing of peace initiatives: Hurting stalemates and ripe moments." Global Review of Ethnopolitics 1 (1): 8-18.

Zenelaj, Reina, Nimet Beriker, and Emre Hatipoglu. 2015. "Determinants of mediation success in post-conflict Bosnia: a focused comparison." Australian Journal of International Affairs 69 (4): 414-437. 